研究

\title{
熱分解法によるマグネタイト被覆センダスト粒子の調製と焼結
}

\author{
小林 秀彦, 箕輪 光, 山本 吉記, 柿崎 浩一, 平塚 信之 \\ 埼玉大学大学院理工学研究科, $\bar{\top} 338$ 浦和市下大久保 255.
}

\section{Preparation and Sintering of Sendust Coated with Magnetite Powders by Pyrolysis}

\author{
Hidehiko Kobayashi, Hikaru Minowa, Yoshinori Yamamoto, Koichi Kakizaki and Nobuyuki Hiratsuka \\ Graduate School of Science and Engineering, Saitama University, 255 Shimo-ohkubo, Urawa 338.
}

Received September 22, 1997

\begin{abstract}
SYNOPSIS
The most suitable producing conditions and degree of densification of sendust (Fe-Si-Al alloy) coated with magnetite powders were investigated from the standpoint of the thermal decomposition. Ferrous formate powders obtained by the precipitation method were used for the coating material of commercial sendust powders. Sendust powders coated with magnetite powders were successfully prepared by pyrolyzing the mixture of fine ferrous formate powders and sendust powders with weight ratio of 1 at $400-1000^{\circ} \mathrm{C}$ for $1 \mathrm{~h}$. The thermal stability of the coated sendust powders under a continued heating at $700-1000^{\circ} \mathrm{C}$ in a $\mathrm{CO}_{2}$ gas flow was significantly high. The degree of densification of the compacts composed of the coated powders and an additive of excess magnetite was higher than those of the compacts with only coated powder, when fired at $1000^{\circ} \mathrm{C}$ for $5 \mathrm{~h}$.
\end{abstract}

KEY WORDS

ferrous formate, sendust powder, sendust coated with magnetite powder, pyrolysis

\section{1 緒 言}

近年の電子機器の小型化, 軽量化にともない, 電子部品には より高周波域においても高初透磁率をもつ磁性材料が要求され ている. しかしながら，磁性材料の共鳴周波数 $\left(\mathrm{f}_{\mathrm{r}}\right)$ と透磁率 $\left(\mu_{\mathrm{r}}\right)$ の積は一定となることが理論的に示されている゙ため, 単体の 磁性材料でこの要求を満足することは困難である。

著者らは本研究において,上述した磁気特性を有する磁性材 料として性質の異なる 2 種類の磁性材料の複合化を提案する. それは金属強磁性材料と酸化物磁性材料の複合化である.一般 に前者は高初透磁率と高飽和磁束密度を有しているが, 抵抗率 が低いために高周波磁界中での渦電流損失が増加し, 初透磁率 が低下する.これに対して後者は抵抗率が高いため, 渦電流の 発生が抑制されて高周波域まで高い初透磁率を示す.したがっ て, 金属強磁性粒子を磁性酸化物で被覆した複合磁性材料は両 者の長所をあわせもつ高周波用材料として期待できる。

金属粒子と酸化物粒子の共存下で加熱操作を行うと, 酸化還 元反応が進行して目的とする酸化物被覆金属精子の調製は困難 となる、そこで, 混合粉末中での酸化還元反応を抑制するため
に, 金属よりも熱的安定性の高い合金の選択と加熱時の雾囲気 制御を導入した. 具体的には, 合金として高初透磁率を示す七 ンダスト $(\mathrm{Fe} 87.4 \mathrm{wt} \%, \mathrm{Si} 7.8 \mathrm{wt} \%, \mathrm{Al} 4.8 \mathrm{wt} \%)^{2)}$ ，酸化物として高 磁化值をもつマグネタイト $\left(\mathrm{Fe}_{3} \mathrm{O}_{4}\right)$ の組み合わせを選び，加熱 時の雲囲気にはマグネタイトの熱的安定性を考慮して $\mathrm{CO}_{2}$ ガス を用いた、まず，沈㪘法で調製したギ酸鉄粉末と市販のセンダ スト粒子の混合粉末を $\mathrm{CO}_{2}$ ガス流通下で熱分解させることによ り，マグネタイト被覆センダスト粒子を合成した，次に，この 被覆粒子の被覆状態およびマグネタイトとセンダストの密着性 を調べた。そして，合成した被覆粒子を用いて成形体を作製 し，その焼結性を調べた。

\section{2 実験方法}

2.1 マグネタイト被覆センダスト粒子の合成

市販の塩化鉄 $\left(\mathrm{FeCl}_{2}\right)$ 粉末を溶媒 $(80 \%$ 水 $+20 \%$ エ夕ノール) に溶解させた後，溶液を穓抖しながら化学量論より10\%過剩量 のギ酸アンモニウム $\left(\mathrm{HCOONH}_{4}\right)$ を加えてギ酸鉄の沈殿物を得 た。この沈殿物中に含まれる水分をロータリーエバポレーター 
で除去して乾燥粉末とした，さらに乾燥粉末中に残存する微 量の水分を除去するために, エ夕ノール溶液中に乾燥粉末を 分散させた後, 水分とエタノールをロータリーエバポレー ターで除去した。

得られた乾燥粉末と市販のセンダスト粒子(Fig.1 粒径: 20 $30 \mu \mathrm{m})$ を混合重量比1:1に秤量した後, めのう乳鉢で十分に混 合した.この混合粉末をアルミナ製ボートに充填し，石英製 反応管に挿入した後, 反応管内を $\mathrm{N}_{2}$ ガスで十分に置換した. その後, $\mathrm{CO}_{2}$ ガス流通下 $\left(100 \mathrm{~cm}^{3} / \mathrm{min}\right)$ で室温から $10 \mathrm{~K} / \mathrm{min}$ の速 度で所定の温度 $\left(400 \sim 1000^{\circ} \mathrm{C}\right)$ まで昇温し, 1 時間保持した後, 反応管を電気炉から引き出して水で急冷して生成物を得た. 2.2 マグネタイト被覆センダスト粒子の密着性

$\mathrm{CO}_{2}$ ガス流通下において 400,500 および $600^{\circ} \mathrm{C} て ゙ 1$ 時間加熱 して合成したマグネタイト被覆センダスト粒子をエタノール 中に分散させた後， $120 \mathrm{~W}$ の超音波洗浄器を用いて $15,30,45$ および60秒間超音波処理した際の被覆粒子の密着性を走查型 電子顕微鏡 (SEM) と振動試料型磁力計 (VSM) を用いて調べ た.

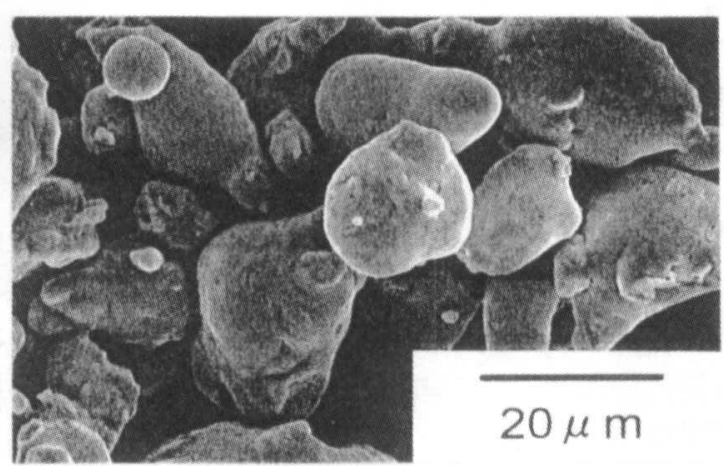

Fig.1 SEM photograph of sendust powders.

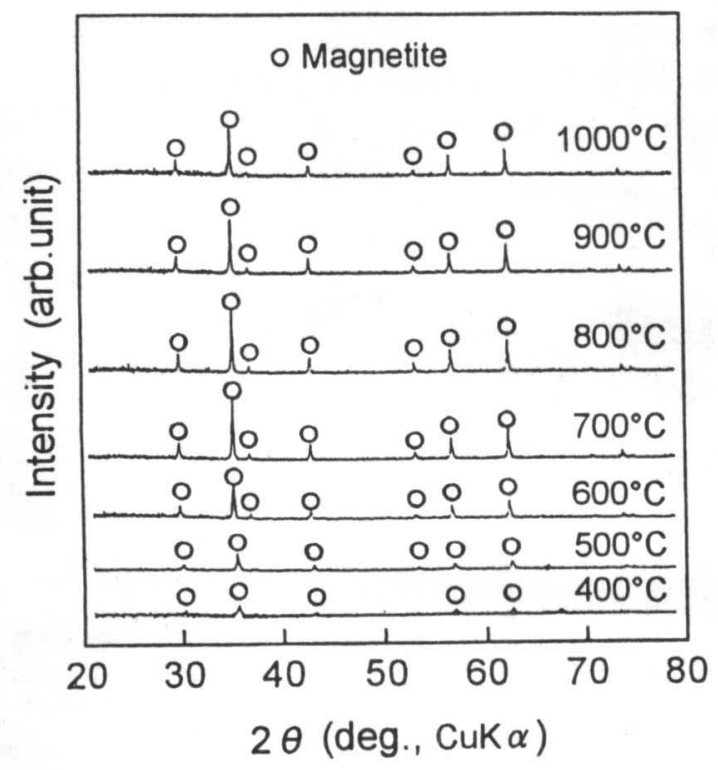

Fig.2 X-ray diffraction patterns of the pyrolytic products heated at $400-1000^{\circ} \mathrm{C}$ for $1 \mathrm{~h}$ in a $\mathrm{CO}_{2}$ gas flow.
2.3 マグネタイト被覆センダスト粒子の焼結

$\mathrm{CO}_{2}$ ガス流通下において $500^{\circ} \mathrm{C} て ゙ 1$ 時間加熱して合成した被 覆粒子を $15 \phi \times 10 \mathrm{~mm}$ の円板形金型に充填し, 一軸加圧成形 (49 MPa) した後CIP処理 $(196 \mathrm{MPa})$ して成形体を作製した.こ の成形体を $\mathrm{CO}_{2}$ ガス流通下, $1000^{\circ} \mathrm{C}$ で 5 時間焼成して焼結体 を作製した，その際の昇温および降温速度は $5 \mathrm{~K} / \mathrm{min}$ とした。 2.4 評価

得られたマグネタイト被覆センダスト粒子の結晶相の同定 および格子定数の測定にはX 線回折装置 (XRD) を，磁気特 性の測定にはVSMを, 粒子形態および焼結体表面の観察には SEMをそれぞれ用いた。

\section{3 実験結果および考察}

3.1 マグネタイト被覆センダスト粒子の合成

シュウ酸鉄を $\mathrm{CO}_{2}$ ガス流通下で熱分解させるとマグネタイ ト単一相が生成することをすでに報告した ${ }^{31}$. 同様の手法で, 沈殿法により調製したギ酸鉄を $\mathrm{CO}_{2}$ ガス流通下で熱分解させ て生成物を調べた．その結果を Fig.2 に示す. $400 〜 1000^{\circ} \mathrm{C}$ の 範囲においてマグネタイトの単一相が合成できた。得られた 粉末の粒子径は SEM 観察から $500^{\circ} \mathrm{C}, 1$ 時間の熱分解条件で 0.2 0.5 $\mu \mathrm{m}$ と微細であった. Fig. 3 に熱分解温度に対するマグ ネタイトの飽和磁束密度を示す. $500 \sim 600^{\circ} \mathrm{C}$ で磁束密度は急 激に増加し， $600^{\circ} \mathrm{C}$ 以上では理論值に等しい $600 \mathrm{mT}^{4}$ に になっ た，合成したマグネタイト粉末は $500^{\circ} \mathrm{C}$ 以下では結晶性が低 く, $600^{\circ} \mathrm{C}$ 以上で結晶化が進行すると考えられる. そこで, 各 熱分解温度ごとのマグネタイトの回折線の主ピークである (311) 面の半価幅を調べた. 半価幅はFig.4に示すように $400^{\circ} \mathrm{C}$ から $600^{\circ} \mathrm{C}$ 範囲で急激に小さくなり, $600^{\circ} \mathrm{C}$ 以上では熱分解 温度の上昇とともにわずかに小さくなる傾向が見られ，マグ ネタイトの結晶化の進行が確認できた。

次に, マグネタイト被覆センダスト粒子の芯となるセンダ

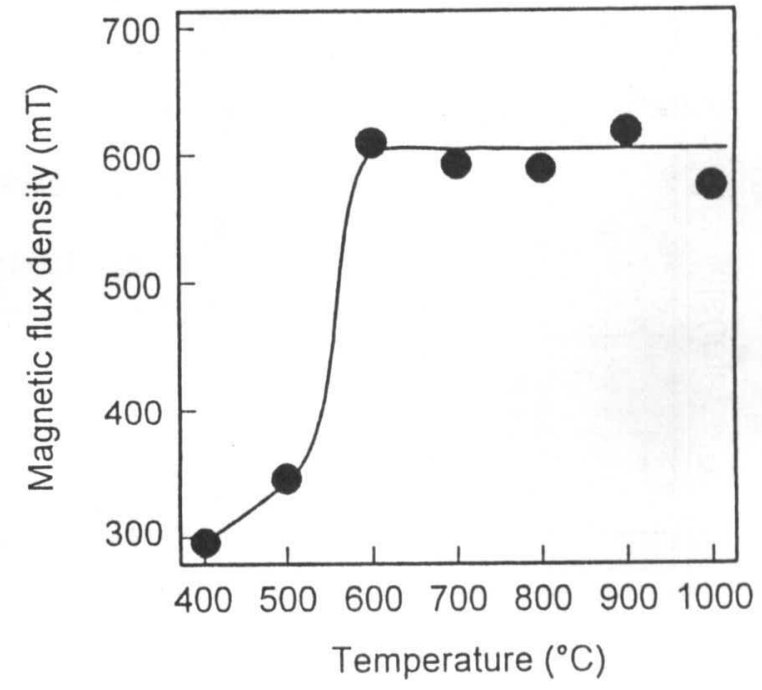

Fig.3 Magnetic flux density of the pyrolytic products heated at $400-1000^{\circ} \mathrm{C}$ for $1 \mathrm{~h}$ in a $\mathrm{CO}_{2}$ gas flow. 


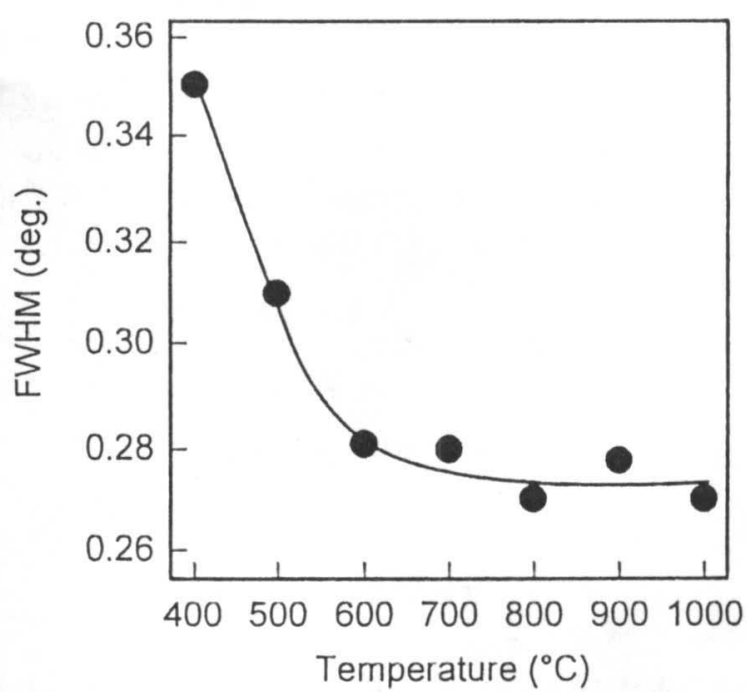

Fig.4 Full width of half maximum intensity (FWHM) of $\mathrm{Fe}_{3} \mathrm{O}_{4}$ (311) plane heated at $400-1000^{\circ} \mathrm{C}$ for $1 \mathrm{~h}$ in a $\mathrm{CO}_{2}$ gas flow.

スト粒子の熱的安定性を調べた. Fig.5に $\mathrm{CO}_{2}$ ガス流通下にお いて $400 \sim 1200^{\circ} \mathrm{C} て ゙ 1$ 時間熱処理したセンダスト粒子の X 線回

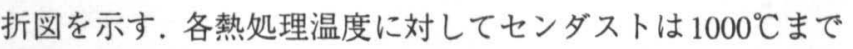

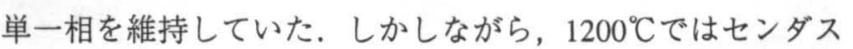
卜相の他に $\mathrm{SiO}_{2}$ と $\mathrm{FeAl}_{2} \mathrm{O}_{4}$ 相が同定され, センダストの回折 線ピークも低角度側ヘシフトしていた。 センダストの格子定

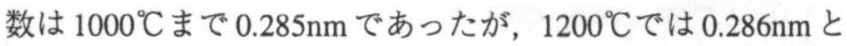
大きくなっており， $\alpha-\mathrm{Fe}$ の格子定数 $0.287 \mathrm{~nm}^{5}$ を考慮すると， センダストの回折線ピークのシフトはSi抢よびAlが脱離した ためと考えられる. 本研究で用いたセンダスト粒子は $1000^{\circ} \mathrm{C}$

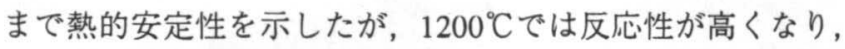
恐らくセンダスト成分中の $\mathrm{Si}$ および $\mathrm{Al}^{\text {保 }} \mathrm{CO}_{2}$ を還元して $\mathrm{SiO}_{2}$

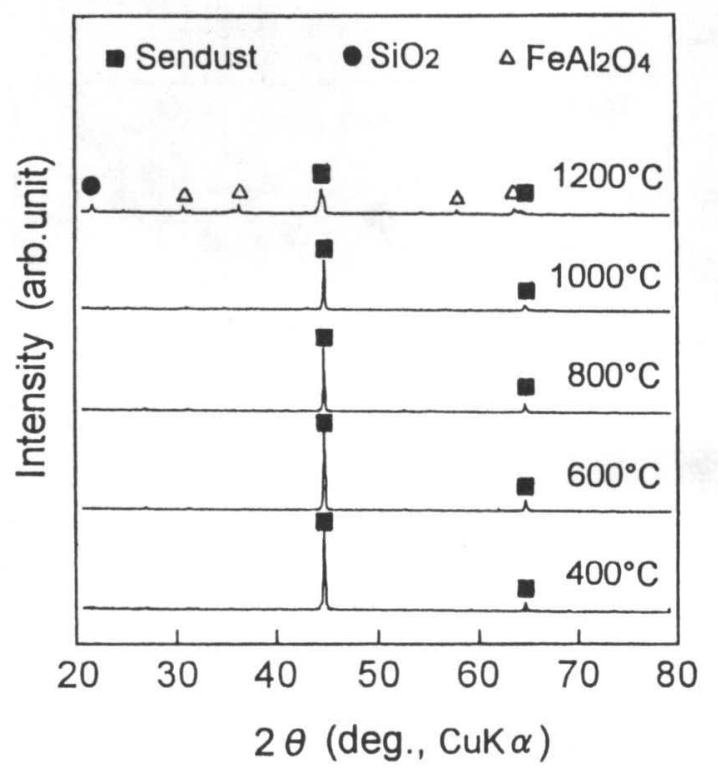

Fig.5 X-ray diffraction patterns of sendut powders heated at $400-$ $1200^{\circ} \mathrm{C}$ for $1 \mathrm{~h}$ in a $\mathrm{CO}_{2}$ gas flow.

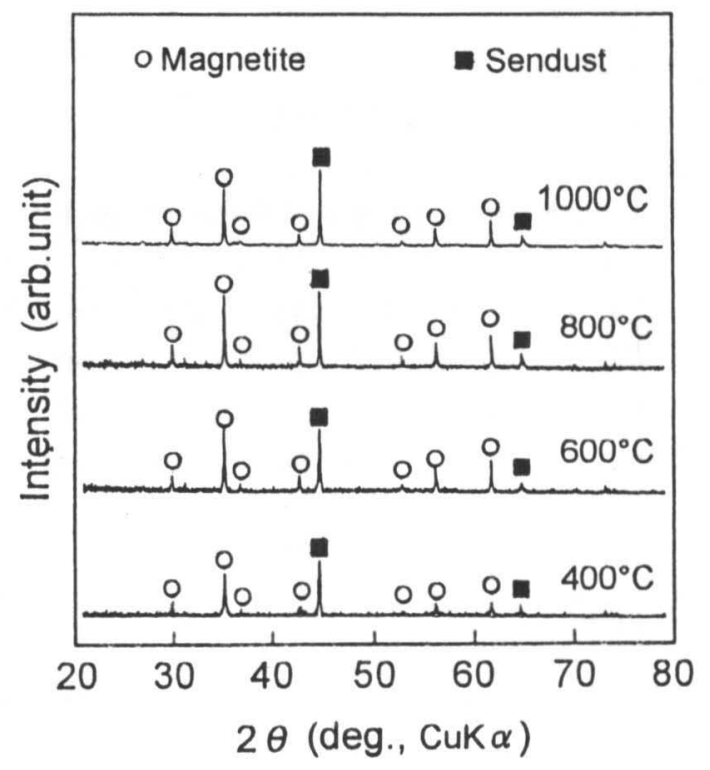

Fig.6 X-ray diffraction patterns of powder mixture of ferrous formate and sendust heated at $400-1000^{\circ} \mathrm{C}$ for $1 \mathrm{~h}$ in a $\mathrm{CO}_{2}$ gas flow.

と $\mathrm{FeAl}_{2} \mathrm{O}_{4}$ を生成したものと推察した.

$\mathrm{CO}_{2}$ ガス流通下における単一相のマグネタイト合成条件と センダスト粒子の熱的安定性の知見から, $400 \sim 1000^{\circ} \mathrm{C}$ の範囲 ではマグネタイトとセンダストはいずれも熱的に安定である と判断できる. そこで, ギ酸鉄粉末とセンダスト粒子の混合 粉末を $\mathrm{CO}_{2}$ ガス流通下, $400 \sim 1000^{\circ} \mathrm{C}$ で 1 時間加熱してマグネ タイト被覆センダスト粒子の合成を試みた. Fig.6に混合粉末 を加熱して得られた生成物の $X$ 線回折図を示す. 生成物はい ずれの加熱温度においてもマグネタイトとセンダストの 2 相 であり，酸化物と金属の共存する粉末が合成できた。これら の粉末をSEM観察したところ, Fig.7に示すように大きなセン ダスト粒子の表面を微細なマグネタイトが緻密に被覆してお り，被覆状態に凹凸が少ないことから，目的とするマグネ夕 イト被覆センダスト粒子が合成できていることが分かった.

3.2 合成した被覆粒子の密着性と熱的安定性

マグネタイト被覆センダスト粒子をエタノール中に分散さ

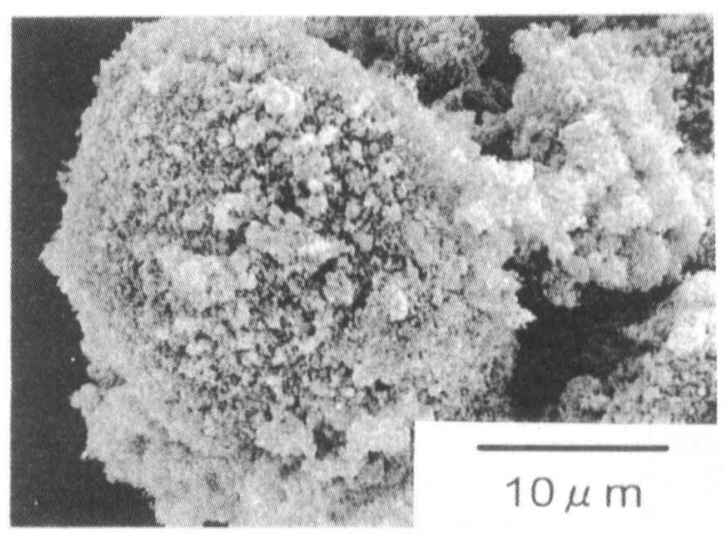

Fig.7 SEM photograph of sendust coated with magnetite powders heated at $500^{\circ} \mathrm{C}$ for $1 \mathrm{~h}$ in a $\mathrm{CO}_{2}$ gas flow. 
せ，超音波を加えて被覆粒子の密着性を調べた。その結果を Fig.8に示す. 超音波処理時間に対する被覆粒子の飽和磁束密 度は各熱分解温度で合成した被覆粒子ともほほ一定値を示し たことから, 被覆粒子を超音波処理してもセンダストを被覆し たマグネタイトの密着性は維持されていると考えられる.一例 として, Fig.9に超音波を 60 秒間印加した後のマグネタイト被覆 センダスト粒子のSEM写真を示す. マグネタイトはセンダスト 粒子表面を緻密に被覆しており，その密着性も良好であった.

合成したマグネタイト被覆センダスト粒子の熱的安定性を $\mathrm{CO}_{2}$ ガス流通下において $700 \sim 1000^{\circ} \mathrm{C} て ゙ 1$ 時間熱処理して調べ た. Fig.10に各熱処理温度に対する被覆粒子の X 線回折図を 示す. $900^{\circ} \mathrm{C}$ まで熱処理温度では結晶相はマグネタイトとセ ンダストの 2 相で, $1000^{\circ} \mathrm{C} て ゙ は$ 単一相のマグネタイトであっ た. また, センダストの回折線ピーク強度が熱処理温度の上 昇とともに小さくなり，1000 ${ }^{\circ} \mathrm{Cで}$ 消失していた，加熱前後で マグネタイトの格子定数に変化は認められず，結晶相もマグ ネタイトの単一相であったので, SEMにより各熱処理温度で の表面状態を観察した. その結果, Fig.11に示すように熱処理 温度の上昇とともにセンダスト粒子を被覆しているマグネタ

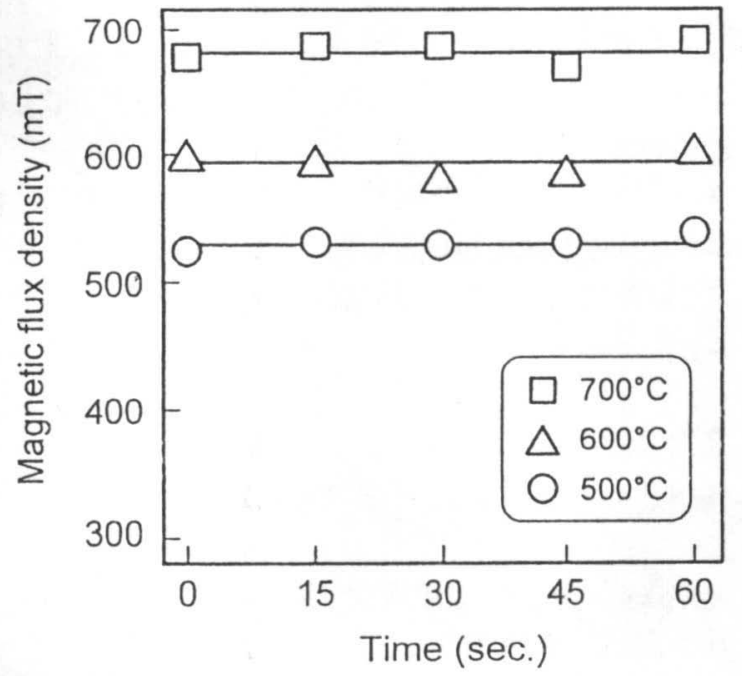

Fig.8 Magnetic flux density of sendust coated with magnetite powders after ultrasonic treatment.

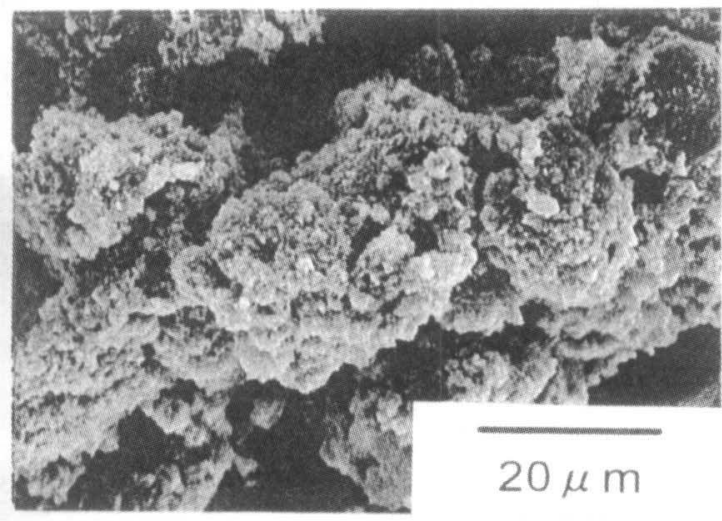

Fig.9 SEM photograph of sendust coated with magnetite powders after ultrasonic treatment for $60 \mathrm{~s}$.
イトの粒成長が顕著であった，上述したセンダストの回折線 ピーク強度の低下の原因は, センダスト表面を被覆しているマ グネタイトの粒成長によるものであり, $\mathrm{CO}_{2}$ ガス流通下では少な くとも $1000^{\circ} \mathrm{C}$ 以下温度でマグネタイト粒子とセンダスト粒子 が共存しても酸化還元反応が進行しないことが分かった.

3.3 マグネタイト被覆センダスト粉末の焼結性

センダストに被覆したマグネタイト粒子の粒成長を利用し

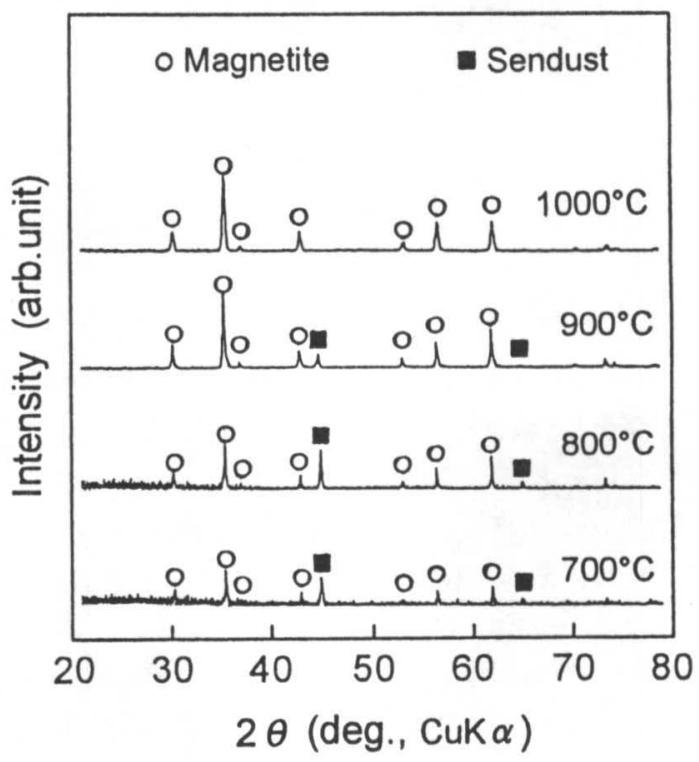

Fig.10 X-ray diffraction patterns of fired sendust with coated magnetite heated at $700-1000^{\circ} \mathrm{C}$ for $1 \mathrm{~h}$ in a $\mathrm{CO}_{2}$ gas flow.
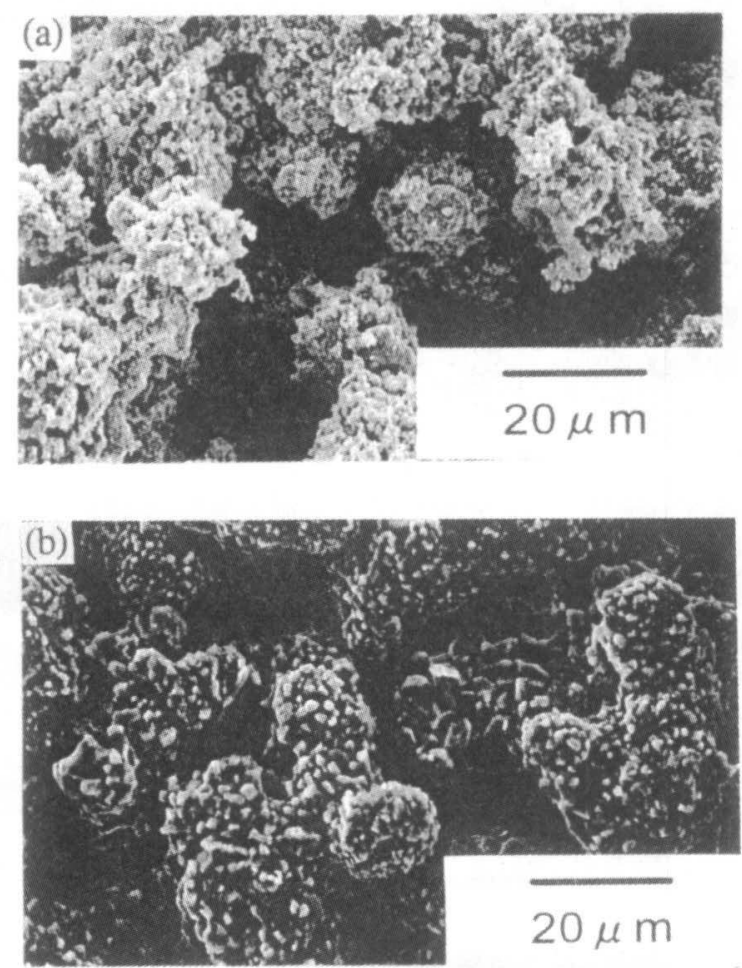

Fig.11 SEM photographs of fired sendust with coated magnetite heated at (a) $700^{\circ} \mathrm{C}$ and (b) $1000^{\circ} \mathrm{C}$ for $1 \mathrm{~h}$ in a $\mathrm{CO}_{2}$ gas flow. 

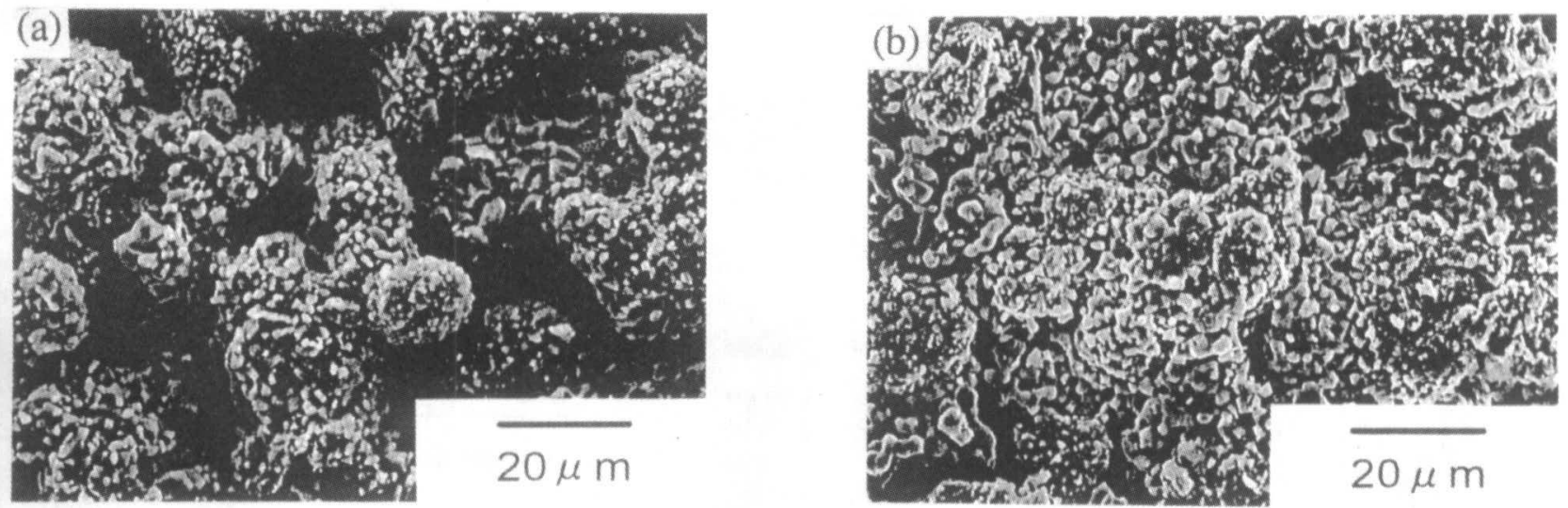

Fig.12 SEM photographs of sintered body fired at $1000^{\circ} \mathrm{C}$ for $5 \mathrm{~h}$ in a $\mathrm{CO}_{2}$ gas flow.

(a) non addition (b) magnetite addition

て緻密な焼結体を作製するために，被覆粒子の合成条件は $\mathrm{CO}_{2}$ ガス流通下, $500^{\circ} \mathrm{C} て ゙ 1$ 時間の加熱とし, 焼結条件はマグ ネタイト粒子とセンダスト粒子の熱的安定性およびマグネタ イトの粒成長を考慮して $\mathrm{CO}_{2}$ ガス流通下に执いて $1000^{\circ} \mathrm{C} て ゙ 5$ 時間の焼成とした. Fig.12(a)に作製した焼結体表面のSEM写 真を示す．センダスト粒子に被覆していたマグネタイトの粒 成長は顕著であったが, 焼結体の緻密化はほとんど進行して いなかった。この原因としては被覆粒子を構成しているマグ ネタイトとセンダストの粒子径がセンダスト $(20 \sim 30 \mu \mathrm{m}) \gg マ$ グネタイト $(0.2 \sim 0.5 \mu \mathrm{m})$ と著しく異なっていることが考えら れ, 成形体作製時での被覆粒子間の空隙を焼成時にマグネ夕 イトの粒成長だけで埋めることが困難であったためと推測し た．そこで成形体の密度を高くするために, 助剤にマグネ夕 イト微粉末を用いて成形体を作製し，上述した焼成条件で焼 結体を作製した．その結果を Fig.12(b)に示す．被覆粒子だけ の焼結体(Fig.12(a)) と比較すると, 助剂を添加した焼結体表面 には空孔が少なく, 緻密化が進行していた，したがって, 緻 密な焼結体を作製するためにはマグネタイト被覆センダスト 粒子の合成時にマグネタイト過剩の混合重量比を用いる必要 があることが分かった。

\section{4 結言}

沈殿法で調製したギ酸鉄粉末と市販のセンダスト粒子を用 いて, $\mathrm{CO}_{2}$ ガス流通下での熱分解によるマグネタイト被覆セ ンダスト粒子の合成条件, 合成した被覆粉末の熱的安定性と 焼結性を調へ, 以下の知見を得た。

（1）沈殿法で調製したギ酸鉄粉末を $\mathrm{CO}_{2}$ ガス流通下において $400 \sim 1000^{\circ} \mathrm{C}$ で1時間熱分解することによりマグネタイト
の単一相が合成できた。

（2）沈殿法で調製したギ酸鉄粉末とセンダスト粒子の混合粉 末を $\mathrm{CO}_{2}$ ガス流通下, $400 \sim 1000^{\circ} \mathrm{C}$ で 1 時間熱分解してセ ンダストとマグネタイトの 2 相粉末が合成できた，合成 した 2 相粉末はマグネタイト被覆センダスト粒子である ことを SEM 観察で確認した。

(3) 合成したマグネタイト被覆センダスト粒子をエタノール 中に分散させて $120 \mathrm{~W}$ の超音波を 60 秒間印加しても被覆 粒子の被覆状態に変化は見られなかった。

(4) 合成したマグネタイト被覆センダスト粒子は助剤にマグ ネタイト微粉末を用いることで, $\mathrm{CO}_{2}$ ガス流通下, $1000^{\circ} \mathrm{C}$ で 5 時間焼成して空孔の少ない焼結体を作製できた。

謝 辞

本研究で使用したセンダスト粒子はTDK(侏)の好意により提 供して頂きました，記して感謝の意を表します．

\section{文献}

1) 近藤, 太田, 安達, 津屋, 石川編: 磁性体ハンドブック, 朝 倉書店, (1975)934.

2）近藤, 太田, 安達, 津屋, 石川編：磁性体ハンドブック, 朝 倉書店, (1975) 1080.

3）小林秀彦, 池田貴志, 三田村孝, 柿崎浩一, 平塚信之: 各 種雾囲気下での熱分解による…, 粉体および粉末治金, 43(1997)89-94.

4) 近藤, 太田, 安達, 津屋, 石川編 : 磁性体ハンドブック, 朝 倉書店, (1975)612.

5) JCPDSカード : No.60696 